\title{
Grape (Vitis vinifera L.) production and soil potassium forms in vineyard subjected to potassium fertilization
}

\author{
Marlise Nara Ciotta ${ }^{1}$, Carlos Alberto Ceretta ${ }^{2}$, Amanda Veridiana Krug ${ }^{3}$, \\ Gustavo Brunetto ${ }^{4}$, Gilberto Nava ${ }^{5}$ \\ Abstract - Potassium fertilization can change $\mathrm{K}$ forms available in the soil, as well as influence plant \\ absorption of it and yield but, mainly, it can affect grape composition. The aim of the current study \\ was to investigate the impact of potassium $(\mathrm{K})$ fertilization on grape production and juice (must) \\ composition of a Cabernet Sauvignon cultivar. Grapevines were treated with 0, 50, 100, 150 and \\ $200 \mathrm{~kg} \mathrm{ha}^{-1}$ year $^{-1} \mathrm{~K}_{2} \mathrm{O}$. Leaf $\mathrm{K}$ contents, grape yield per plant and area, total soluble solids (TSS), \\ must $\mathrm{pH}$ and titratable acidity, and $\mathrm{K}$ available in the soil were assessed. Soil samples collected at \\ the 20-cm layer were analyzed to measure $\mathrm{K}$ availability and nonexchangeable $\mathrm{K}$ in them, based \\ on studies conducted over 3 growing seasons. Results have shown that $\mathrm{K}$ application did not have \\ effect on grape production and must composition, although it increased $\mathrm{K}$ contents in leaf blade and \\ petiole. However, annual $\mathrm{K}$ fractionation in the soil has suggested that $100 \mathrm{~kg} \mathrm{ha}^{-1}$ year-1 $^{-1} \mathrm{~K}_{2} \mathrm{O}$ is the \\ $\mathrm{K}$ dose capable of maintaining $\mathrm{K}$ availability to plants at more appropriate contents throughout the \\ growing seasons. \\ Index terms: Vitis vinifera, $\mathrm{K}$ fertilizer rates; yield components; $\mathrm{K}$ in berry; chemical fractionation \\ of $\mathrm{K}$.

\section{Produção de uva, composição do mosto e alterações de formas de potássio no solo em vinhedos submetidos à adubação potássica}

Corresponding author: marlise@epagri.sc.gv.br

Received: March 16, 2020 Accepted: December 07, 2020

Copyright: All the contents of this journal, except where otherwise noted, is licensed under a Creative Commons Attribution License.

\section{(cc) $\mathrm{EY}$}

Resumo - A adubação potássica pode modificar as formas de K no solo, influenciando a absorção pela planta e a produtividade, mas principalmente a composição da uva. O objetivo do presente estudo foi avaliar o impacto da fertilização com potássio $(\mathrm{K})$ na uva, a produção e a composição do mosto de uva da cultivar 'Cabernet Sauvignon'. As videiras foram tratadas com 0;50;100;150 e $200 \mathrm{~kg} \mathrm{ha}^{-1}$ ano $^{-1}$ de $\mathrm{K}_{2} \mathrm{O}$. Foram avaliados os teores de $\mathrm{K}$ na folha, a produção de uva por planta e por área, os sólidos solúveis totais (SST), o pH do mosto e a acidez titulável no mosto, e o $\mathrm{K}$ disponível no solo. Amostras de solo coletadas na camada superficial de $20 \mathrm{~cm}$ foram analisadas para medir a disponibilidade de $\mathrm{K}$ e o $\mathrm{K}$ não trocável, com base em estudos conduzidos ao longo de 3 safras. Os resultados mostraram, pela análise das três safras da videira, que a aplicação de $\mathrm{K}$ não afetou a produção e a composição do mosto, embora tenha aumentado o teor de $\mathrm{K}$ na folha. No entanto, o fracionamento anual de $\mathrm{K}$ do solo sugere que $100 \mathrm{~kg} \mathrm{ha}^{-1} \mathrm{ano}^{-1}$ de $\mathrm{K}_{2} \mathrm{O}$ é a dose de $\mathrm{K}$ capaz de manter a disponibilidade do nutriente para as plantas em teores mais adequados ao longo das estações de cultivo.

Termos para indexação: Vitis vinifera, doses de adubação potássica, componentes do rendimento, potássio na baga, fracionamento químico do potássio.

\footnotetext{
${ }^{1}$ Doctora in Soil Science, Researcher of Empresa de Pesquisa Agropecuária e Extensão Rural de Santa Catarina, Lages-SC, Brazil, Email: marlise@epagri.sc.gv.br (ORCID 0000-0002-9807-2912)

${ }^{2}$ Doctor in Soil Science, Retired Prof. and collaborator of Departament of Soil Science and Graduate Studies Program in Soil Science (UFSM), Santa Maria-RS, Brazil.Email:carlosceretta@ufsm.br(ORCID 0000-0003-2948-1111)

${ }^{3}$ M.Sc. In Soil Science of Graduate Studies Program in Soil Science (UFSM), Santa Maria-RS, Brazil, E-mail: krug.amanda111@gmail.com (ORCID 0000-0003-1434-849X)

${ }^{4}$ Doctor in Soil Science, Prof. of Soil Science and Plant Nutrition, Departament of Soil Science and Graduate Studies Program in Soil Science (UFSM), Santa Maria-RS, Brazil, Email: brunetto.gustavo@gmail.com (ORCID 0000-0002-7260-7907)

${ }^{5}$ Doctor in Soil Science, Researcher of Embrapa de Clima Temperado, Pelotas-RS, Brazil, Email: gilberto.nava@embrapa.br ${ }^{(0 R C I D}$ 0000-00028059-1052)
} 


\section{Introduction}

The Brazilian Southern Region, where Santa Catarina State is located in, has a large area used to grow Cabernet Sauvignon grape (SILVA; RODRIGUES, 2018). Cabernet Sauvignon is the most cultivated grapevine for red wine production. However, grape production and composition may be affected by potassium $(\mathrm{K})$, which may also change the distribution of nutrient fractions in vineyard soils. Once $\mathrm{K}$ is absorbed by plants, it is transported through the xylem to the leaves and other organs, mainly to those involved in cell division processes (BACHTELER et al., 2013; BENITO et al., 2013; KUMARAN et al., 2019). Potassium (K) concentration in the leaves can be used to diagnose the nutritional status of plants (STELLACCI et al., 2010; TAGLIAVINI; SCANDELLARI, 2013; ARROBAS et al., 2014; DOMAGALA-SWIATKIEWICZ et al., 2019).

Potassium (K) available in the soil can be taken up by plants and transported to the leaves and berries. The amount of it in berry clusters can represent more than $50 \%$ of $\mathrm{K}$ found in plants (MPELASOKA et al., 2003 ). Berries present $59 \%$ of $\mathrm{K}$ in the pulp and $32 \%$ of it is in the skin (BERTOLDI et al., 2011; ROGIERS et al., 2017). The role played by $\mathrm{K}$ in grape clusters is associated with enzymatic synthesis and activation reactions, which directly contribute to proper berry ripening, sugar concentration and cell turgor maintenance (OSAKABE et al., 2013, ZLÁMALOVÁ et al., 2015; KAMIRI et al., 2017; EL-BADAWY, 2019). Furthermore, $\mathrm{K}$ plays a key role in solute transportation, assimilates' partitioning, and in the synthesis of several polyphenols that account for grape color and aroma (LESTER et al., 2010; RAMOS; ROMERO, 2016). Thus, K can affect must composition, mainly when it is applied to soils at higher concentrations than the ones required for grapevines. Optimal wine $\mathrm{pH}$ should not exceed 3.5 (MPELASOKA et al., 2003). However, for several reasons, $\mathrm{K}$ levels exceeding plant requirements may lead to increased $\mathrm{pH}$. First, the stoichiometric exchange of acid protons $\left(\mathrm{H}^{+}\right)$by $\mathrm{K}$ may take place and form $\mathrm{K}$ bitartrate, which is a salt that precipitates in wine and impairs its quality. On the other hand, excessive $\mathrm{K}$ fertilization does not increase grape production (DELGADO et al., 2004; BOONTERM et al., 2010; DAL BO et al., 2015; CIOTTA et al., 2016; NIEVES-CORDONES, et al., 2019), but it can affect enzymatic reactions, protein and carbohydrate synthesis, photosynthesis and cell osmotic potential control (MPELASOKA et al., 2003; CHAVES et al., 2016; ROGIERS et al., 2017), just as other nutrients affect plant physiology.

Part of the applied K can be absorbed by cation exchange sites in the soil or be immobilized in clay mineral interlayers. The rate and direction of reactions between the solution and exchangeable $\mathrm{K}$ forms determine whether the applied $\mathrm{K}$ will be leached into lower horizons, taken up by plants, converted into unavailable forms, or released into available forms (MEHLICH, 1953). Different $\mathrm{K}$ pools can be removed from the soil by using different extractants. Potassium $(\mathrm{K})$ available in plants is often determined through Mehlich-1 extractor (SIMONSSON et al., 2009), whereas non-exchangeable $\mathrm{K}$ can be extracted by boiling $1 \mathrm{~mol} \mathrm{~L}^{-1} \mathrm{HNO}_{3}$ Total $\mathrm{K}$ in the soil can be extracted through hydrofluoric acid (HF). Vineyard soils that are not subjected to K fertilizer addition, or that are subjected to the addition of doses that fail to meet grapevine requirements, may show decreased $\mathrm{K}$ concentration in soil solution, in both exchangeable and non-exchangeable forms, due to nutrient adsorption and export by grape clusters (PRADUBSUK; DAVENPORT, 2010; TEIXEIRA et al., 2011). The aim of the present study was to assess how $\mathrm{K}$ fertilization can affect grape production, must composition and $\mathrm{K}$ forms available in the soil.

\section{Materials and methods}

\section{Experiment description}

The experiment was conducted in a vineyard located in São Joaquim County, mountainous region of Santa Catarina State (SC), Southern Brazil (latitude $28^{\circ} 17^{\prime} 25^{\prime}$ ' S, longitude $49^{\circ} 56^{\prime} 56^{\prime}$ ' W, altitude of $1,280 \mathrm{~m}$ ), in the $2010 / 11,2011 / 12$ and 2012/13 growing seasons. Soil was classified as Haplumbrept (Humic Cambisol) and, until 2002, it was covered with natural vegetation comprising species such as Andropogon lateralis, A. selloanus, Paspalum notatum and Baccharis gaudichaudiana. Mineralogical analysis of the soil has indicated incidence of vermiculite and kaolinite in it. Soil analysis has indicated $42 \mathrm{~g} \mathrm{~kg}^{-1}$ of clay and $4.4 \mathrm{~g} \mathrm{~kg}^{-1}$ of organic matter. Surface soil $\mathrm{pH}_{1: 1}$ was 5.8. Exchangeable $\mathrm{Ca}, \mathrm{Mg}, \mathrm{P}, \mathrm{K}$; effective CEC; CEC pH 7.0 and base saturation reached $10 \mathrm{cmol}_{\mathrm{c}} \mathrm{kg}^{-1}, 4.9 \mathrm{cmol}_{\mathrm{c}} \mathrm{kg}^{-1}, 3.2 \mathrm{mg} \mathrm{kg}$ 1, $95 \mathrm{mg} \mathrm{kg}^{-1}, 15.3 \mathrm{cmol}_{\mathrm{c}} \mathrm{kg}^{-1}, 17.2 \mathrm{cmol}_{\mathrm{c}} \mathrm{kg}^{-1}$ and $87.2 \%$, respectively. According to Köppen's classification (1931), the climate in the region is classified as $\mathrm{Cfb}$ ('Clima de altitude'), mesothermal, humid with rainfall events in all months of the year and cool summer $\left(22^{\circ} \mathrm{C}\right)$. Normal mean maximum temperature ranges from $19.4^{\circ} \mathrm{C}$ to $22.4^{\circ} \mathrm{C}$, whereas minimum temperature ranges from $9.2^{\circ} \mathrm{C}$ to $10.8^{\circ} \mathrm{C}$; it is possible having 20 to 29 frosts per year. Total annual rainfall ranged from $1,360 \mathrm{~mm}$ to $1,600 \mathrm{~mm}$, with total number of approximately 135 days of rain events per year. Relative air humidity ranges from $80 \%$ to 83 $\%$, whereas total insolation ranges from 1,824 to 2,083 hours. Climate data collected throughout the study are shown in Table 1. 
Table 1. Mean rainfall, air temperature and insolation per month in 2011, 2012 and 2013

\begin{tabular}{lccccccccc}
\hline \multirow{2}{*}{ Months } & \multicolumn{3}{c}{ Rainfall $(\mathrm{mm})$} & \multicolumn{3}{c}{ Air Temperature $\left({ }^{\circ} \mathrm{C}\right)$} & \multicolumn{3}{c}{ Insolation(hours) } \\
\cline { 2 - 9 } Jan & 2011 & 2012 & 2013 & 2011 & 2012 & 2013 & 2011 & 2012 & 2013 \\
Feb & 354.3 & 209.6 & 66.5 & 18.3 & 16.5 & 16.1 & 157.6 & 194.8 & 215.3 \\
Mar & 188.8 & 60.5 & 247.1 & 17.6 & 18.6 & 16.3 & 104.9 & 154.1 & 137.5 \\
Apr & 118.8 & 88.8 & 48.5 & 14.2 & 13.7 & 13.4 & 176.9 & 162.2 & 218.7 \\
Mai & 100.1 & 31.9 & 75.6 & 10.0 & 11.2 & 11.3 & 154.4 & 195.9 & 161.9 \\
Jun & 143.3 & 154.3 & 184.6 & 8.5 & 10.1 & 10.2 & 124.6 & 174.8 & 125.0 \\
Jul & 239.6 & 168.3 & 67.7 & 9.8 & 8.6 & 9.2 & 132.9 & 153.8 & 205.3 \\
Aug & 368.8 & 19.1 & nd & 9.8 & 12.8 & nd & 114.6 & 199.7 & nd \\
Sep & 145.2 & 146.4 & nd & 11.2 & 12.3 & nd & 187.5 & 164.5 & nd \\
Oct & 168.4 & 181.2 & nd & 13.7 & 14.9 & nd & 191.6 & 132.8 & nd \\
Nov & 232.7 & 50.7 & nd & 14.1 & 15.1 & nd & 189.5 & 213.1 & nd \\
Dec ${ }^{(1)}$ & 167.8 & 178 & nd & 15.4 & 18.6 & nd & 187.7 & 151.8 & nd \\
\hline
\end{tabular}

${ }^{(1}$ The incidence of storm throughout the month, in 2011.nd = not determined

The vineyard was established in May 2002, when lime was applied to the soil surface to raise water $\mathrm{pH}$ to 6.5 and $300 \mathrm{~kg} \mathrm{ha}^{-1} \mathrm{P}_{2} \mathrm{O}_{5}$ was applied to soil surface in the form of triple superphosphate $\left(41 \% \mathrm{P}_{2} \mathrm{O}_{5}\right)$. Lime and triple superphosphate were incorporated to soil layer $0.20 \mathrm{~m}$ with the aid of a disk harrow attached to a tractor. The soil was subjected to harrowing, right away. Cabernet Sauvignon cultivar seedlings, grafted on Paulsen 1103 rootstock, were transplanted in July 2002 at the density of 2,666 plants per hectare $(1.5 \times 2.5 \mathrm{~m})$. Grapevines were grown under trellis system, without irrigation.

The experiment was set up in July 2010, when 0 , $50,100,150$ and $200 \mathrm{~kg} \mathrm{ha}^{-1} \mathrm{year}^{-1}$ of $\mathrm{K}_{2} \mathrm{O}$ were applied once a year, during winter. $\mathrm{KCl}$ was the herein adopted $\mathrm{K}$ fertilizer $\left(58 \% \mathrm{~K}_{2} \mathrm{O}\right)$. These treatments provided approximately $0,42,83,125$ and $166 \mathrm{~kg} \mathrm{ha}^{-1} \mathrm{year}^{-1}$ of K. During the experiment, $80 \mathrm{~kg} \mathrm{ha}^{-1}$ year $^{-1}$ of $\mathrm{N}$, in the form of urea, was annually applied in three split applications at baseline, and after 30 and 60 sprouting days; $40 \mathrm{~kg} \mathrm{ha}^{-}$ ${ }^{1}$ year ${ }^{-1}$ of $\mathrm{P}_{2} \mathrm{O}_{5}$, in the form of triple superphosphate, was also applied. All fertilizers were applied to soil surface without soil incorporation. The study has followed a randomized block experimental design with five repetitions. Each plot comprised seven plants; the five central plants were evaluated.

Soil collection and chemical fractionation of $\mathrm{K}$

Soil samples were collected from soil surface $(0.00$ $0.20 \mathrm{~m}$ layer) at plant canopy projection, in July. They were dried in forced-air oven at $40{ }^{\circ} \mathrm{C}$, ground, sieved (2-mm mesh) and stored for further analysis. Available $\mathrm{K}$ was extracted from all soil samples using Mehlich-1 solution $\left(0.05 \mathrm{~mol} \mathrm{~L}^{-1}\right.$ of $\mathrm{HCl}+0.0125 \mathrm{~mol} \mathrm{~L}^{-1}$ of $\left.\mathrm{H}_{2} \mathrm{SO}_{4}\right)$ (MEHLICH, 1953). Non-exchangeable $\mathrm{K}$ was determined based on the difference between soluble content in boiling $1 \mathrm{~mol} \mathrm{~L}^{-1}$ of $\mathrm{HNO}_{3}$ (PRATT, 1965) and available $\mathrm{K}$ for Mehlich-1. Total K was extracted by using concentrated hydrofluoric acid solution on heating plate. Potassium (K) contents extracted based on three different methods were assessed in flame photometer (HELMKE and SPARKS, 1996).

\section{Leaf collection and total $K$ content analysis}

Five complete leaves (blade + petiole) located on the side opposite to the first cluster of the branch were collected per plant in the 2011/12 and 2012/13 growing seasons, at full bloom. Leaves were separated into blade and petiole, dried at $65^{\circ} \mathrm{C}$, ground, digested in acidic solution (perchloric and nitric acid) and subjected to total $\mathrm{K}$ analysis in flame photometer (RAMOS; ROMERO; 2016; CIOTTA et al., 2016).

\section{Grape production and chemical analysis of the} must

All clusters per plant were collected, counted and weighed in portable digital scale (5000-g capacity), at berry maturation stage (April), in the three investigated growing seasons. Five clusters were reserved per plant; subsequently, berries were collected from the upper, middle and bottom parts of each cluster. The mass of 100 berries was measured in analytical scale; must was produced by separating berries' peel from seed. Must was analyzed for Total Soluble Solids (TSS), pH, total titratable acidity (TTA) and total K (BRUNETTO et al., 2012; CIOTTA et al., 2016).

\section{Statistical analysis}

ANOVA was used to determine the effects of each treatment, which were considered random. Regression equations were fitted to the means, and the best model was selected based on the F-test at error probability lower than $5 \%(\mathrm{p}<0.05)$, whenever treatment effects were statistically significant. Mean differences were determined through Tukey's test $(\mathrm{p}<0.05)$. 
Parameters such as grape yield, $\mathrm{pH}$, total titratable acidity and must TSS; K in berries; and available, nonexchangeable and total $\mathrm{K}$ in the soil at the $2010 / 11$ growing season were analyzed based on principal components analysis (PCA), as well as total $\mathrm{K}$ in the petiole at growing seasons 2011/12, 2012/13.

\section{Results and discussion}

\section{$K$ contents in the soil}

Available K has linearly increased as K fertilizer rate in the grapevine of the three analyzed growing seasons also increased (Table 2). K contents in control soils were higher in the 2010/11 and 2011/12 growing seasons than in the 2012/13 growing season. The highest $\mathrm{K}$ content in the soil was associated with the treatment with $200 \mathrm{~kg} \mathrm{ha}^{-1}$ of $\mathrm{K}_{2} \mathrm{O}$ in the 2012/13 growing season. DOMAGALASWIATKIEWICZ et al., (2019) evaluated different K doses applied to the soil and observed increased rates for this nutrient at dose application up to $100 \mathrm{Kg}$ of $\mathrm{K}(50 \%$ $\mathrm{K}_{2} \mathrm{O}$ ).

Table 2. Potassium extracted through Mehlich 1, non-exchangeable $\mathrm{K}$ extracted through boiling $\mathrm{HNO}_{3} 1 \mathrm{~N}$, and total $\mathrm{K}$ extracted through hydrofluoric acid, from the 0-00 to 0-20 m layers in soil cultivated with Cabernet Sauvignon vines and subjected to $\mathrm{K}$ fertilizer rates during three different growing seasons.

\begin{tabular}{|c|c|c|c|c|c|c|c|}
\hline \multirow{2}{*}{ Season } & \multicolumn{5}{|c|}{ Dose $\left(\mathrm{kg} \mathrm{ha}^{-1}\right.$ per year-1 of $\left.\mathrm{K}_{2} \mathrm{O}\right)$} & \multirow[t]{2}{*}{ Equation } & \multirow[t]{2}{*}{$\mathrm{R}^{2}$} \\
\hline & 0 & 50 & 100 & 150 & 200 & & \\
\hline \multicolumn{8}{|c|}{-------Available (mg kg) ------- } \\
\hline 2010/11 & $90 \mathrm{a}$ & $151 \mathrm{a}$ & $182 \mathrm{a}$ & $257 \mathrm{a}$ & $345 b$ & $\hat{y}=81.8+1.232 * x$ & 0.97 \\
\hline $2011 / 12$ & $76 a$ & $129 b$ & $195 \mathrm{a}$ & $266 \mathrm{a}$ & $349 b$ & $\hat{y}=66.4+1.366^{*} x$ & 0.97 \\
\hline $2012 / 13$ & $50 \mathrm{~b}$ & $90 \mathrm{c}$ & $103 b$ & $274 a$ & $464 \mathrm{a}$ & $\hat{y}=-6.2+2.024 * x$ & $0.86^{*}$ \\
\hline $\mathrm{CV} \%$ & 10.41 & 8.60 & 7.52 & 10.85 & 6.02 & & \\
\hline \multicolumn{8}{|c|}{-------Non-exchangeable K (mg kg-1) -------- } \\
\hline 2010/11 & $202 \mathrm{a}$ & $286^{\mathrm{a}}$ & $291 b$ & $366 b$ & $451 \mathrm{c}$ & $\hat{y}=203.6+1.156^{*} x$ & 0.95 \\
\hline $2011 / 12$ & $129 b$ & $218 b$ & $295 b$ & $360 \mathrm{~b}$ & $572 b$ & $\hat{y}=109.2+2.056^{*} x$ & 0.94 \\
\hline $2012 / 13$ & $126 \mathrm{~b}$ & $197 \mathrm{c}$ & $374 \mathrm{a}$ & $439 \mathrm{a}$ & $748 \mathrm{a}$ & $\hat{y}=79.6+2.972 * x$ & 0.93 \\
\hline $\mathrm{CV} \%$ & 5.89 & 3.57 & 8.83 & 5.05 & 4.34 & & \\
\hline \multicolumn{8}{|c|}{----------Total K $\left(\mathrm{mg} \mathrm{kg}^{-1}\right)$ - -------- } \\
\hline $2010 / 11$ & $418 \mathrm{a}$ & $427 \mathrm{a}$ & $438 \mathrm{a}$ & $502 b$ & $604 b$ & $\hat{y}=388.4+0.894 * x$ & 0.83 \\
\hline $2011 / 12$ & $408 \mathrm{a}$ & $421 \mathrm{a}$ & $434 \mathrm{a}$ & $526 \mathrm{~b}$ & $674 b$ & $\hat{y}=365.2+1.274 * x$ & 0.82 \\
\hline $2012 / 13$ & $406 \mathrm{a}$ & $406 \mathrm{a}$ & $480 \mathrm{a}$ & $576 \mathrm{a}$ & $800 \mathrm{a}$ & $\hat{y}=342.0+1.916^{*} x$ & 0.85 \\
\hline $\mathrm{CV} \%$ & 6.75 & 6.42 & 6.13 & 3.34 & 10.00 & & \\
\hline
\end{tabular}

(1)

Means followed by the same letter in the column did not differ from each other, at $5 \%$ probability level

The amount of non-exchangeable $\mathrm{K}$ has linearly increased as fertilizer rates also increased (Table 2). The highest non-exchangeable $\mathrm{K}$ contents were recorded for the 100,150 and $200 \mathrm{~kg} \mathrm{ha}^{-1} \mathrm{~K}_{2} \mathrm{O}$ treatments in the 2012/13 growing season. Total $\mathrm{K}$ contents have linearly increased as $\mathrm{K}$ fertilizer rates also increased (Table 2).

These results were attributed to plants that only used a fraction of the applied K. High K fertilizer doses, whose $\mathrm{K}$ amount might have exceeded grapevine requirements, may have led to the redistribution of part of the nutrient to interlayers of 2:1 clay minerals in the soil. This process may have increased non-exchangeable $\mathrm{K}$ mineral contents due to the presence of the interlayer presenting ditrigonal pore dimensions capable of adjusting the $\mathrm{K}^{+}$radius to enable its chemical adsorption or fixation. This may include vermiculite, other interstratified minerals or even partly weathered micas, which also show surface charges (SHANGE; CONRADIE, 2012).
Decreased available $\mathrm{K}$ and non-exchangeable $\mathrm{K}$ contents in control soils were attributed to K uptake by plants since there is equilibrium relationship between these two pools (Tables 2 and 3). When solution $\mathrm{K}$ decreases due to root absorption, exchangeable $\mathrm{K}$ forms in the soil primarily replenish this amount in order to maintain nutrient balance. However, up to a certain limit, $\mathrm{K}$ may be supplied through exchangeable reserves in the soil without the need of high $\mathrm{K}$ fertilization contents. Thus, exchangeable $\mathrm{K}$ represents the main $\mathrm{K}$ species available for plant nutrition. Soils presenting different CEC have different abilities to control $\mathrm{K}$ concentrations in the solution (buffering). The desorption of non-exchangeable $\mathrm{K}$ forms, which may contribute to plant nutrition, may take place if the low $\mathrm{K}$ concentration in the solution persists over time and if the exchangeable $\mathrm{K}$ forms are depleted (SIMONSSON et al., 2009; HOU et al., 2019). 
Table 3. Grape production, yield components, total K content in berry and total K content in limbo and petioles of Cabernet Sauvignon vines subjected to the application of different $\mathrm{K}$ fertilizer rates for three growing seasons.

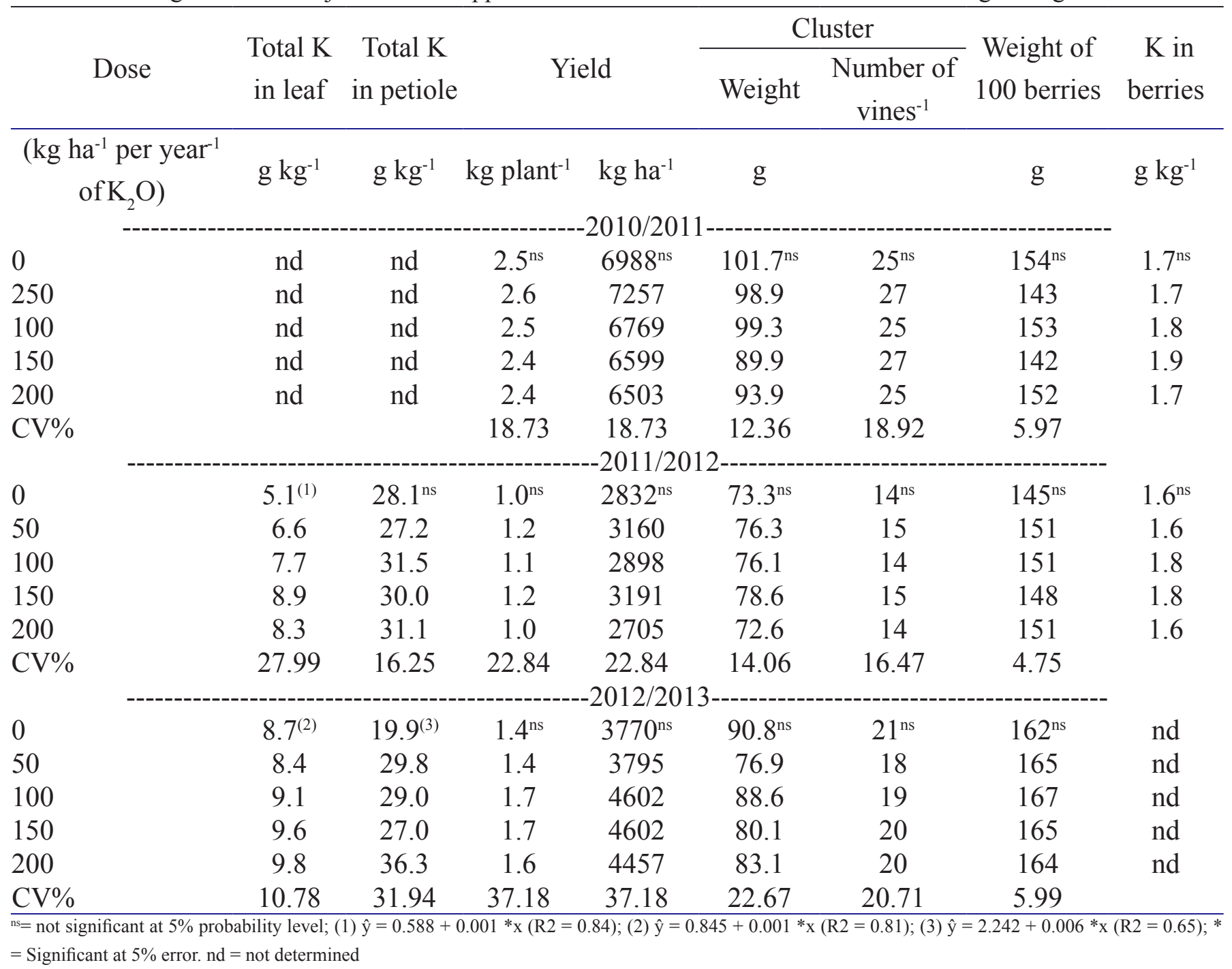

Total tissue K, grape yield and must composition

Total $\mathrm{K}$ contents in leaf blades have linearly increased as fertilizer rates also increased in the 2011/12 and 2012/13 growing seasons (Table 3 ). Total $\mathrm{K}$ contents in leaf blade have increased from $5.1 \mathrm{~g} \mathrm{~kg}^{-1}$ in plants that were not subjected to $\mathrm{K}$ fertilizer application to $8.3 \mathrm{~g} \mathrm{~kg}^{-1}$ in leaf blades of grapevines subjected to annual addition of $200 \mathrm{~kg} \mathrm{ha}^{-1}$ year ${ }^{-1}$ of $\mathrm{K}_{2} \mathrm{O}$. Critical $\mathrm{K}$ values in leaves ranged from 8.0 to $16.0 \mathrm{~g} \mathrm{~kg}^{-1}$ (CQFS-RS/SC, 2016).

Total $\mathrm{K}$ contents in leaf blades of grapevines that were not subjected to $\mathrm{K}$ fertilizer application in the 2012/2013 growing season reached $8.7 \mathrm{~g} \mathrm{~kg}^{-1}$ and they increased to $9.8 \mathrm{~g} \mathrm{~kg}^{-1}$ in leaf blades of plants subjected to annual addition of $200 \mathrm{~kg} \mathrm{ha}^{-1}$ year ${ }^{-1}$ of $\mathrm{K}_{2} \mathrm{O}$. Potassium (K) fertilizer application has failed to change total $\mathrm{K}$ contents in the petiole in the 2011/12 growing season, although these contents have linearly increased from $19.9 \mathrm{~g} \mathrm{~kg}^{-1}$ in plants that were not subjected to $\mathrm{K}$ fertilizer application to $3.63 \%$ in plants subjected to annual addition of $200 \mathrm{~kg} \mathrm{ha}^{-1}$ year $^{-1}$ of $\mathrm{K}_{2} \mathrm{O}$ in the 2012/2013 growing season. These results were attributed to increased exchangeable $\mathrm{K}$ contents and nutrient availability in the soil, which may have reached roots' outer surface due to mass flow or, mainly, to diffusion. Other studies have reported similar results. Walker and Blackmore (2012) have also noticed increased $\mathrm{K}$ contents in grapevine leaf petioles of Chardonnay and Shiraz cultivars grafted into different rootstocks grown in soils presenting increasing exchangeable $\mathrm{K}$ contents in a long-term experiment conducted in Australia.

Pradubsuk and Davenport (2010) have reported that Concord grape leaf petioles presented $30.0 \mathrm{~g} \mathrm{~kg}^{-1}$ of K, whereas Cabernet Sauvignon leaf petioles presented $36.3 \mathrm{~g}$ $\mathrm{kg}^{-1}$ of it. Dooa et al. (2019) have also observed increased $\mathrm{K}$ levels in grapevine petiole due to $\mathrm{K}$ fertilizer application on the soil or leaves. Overall, normal $\mathrm{K}$ contents in leaf petioles ranged from 15.1 to $25.0 \mathrm{~g} \mathrm{~kg}^{-1}$ (CQFS-RS/SC, 2016). 
Mean cluster mass, mass of 100 berries and number of clusters per plant were not influenced by $\mathrm{K}$ fertilization (Table 3). Grape yield has also failed to respond to $\mathrm{K}$ fertilizer application despite significant yield variations, namely: $6.82 \mathrm{~kg}$ grape $\mathrm{ha}^{-1}$ year-1 $^{-1}$ in the 2010/11 growing season and $2.96 \mathrm{~kg}_{\text {grape }} \mathrm{ha}^{-1}$ year $^{-1}$ in the 2011/12 growing season. Total K contents in berries did not show effect of $\mathrm{K}$ fertilizer application in any growing season (Table 3 ). Lack of $\mathrm{K}$ effect on grape yield was attributed to sufficient available $\mathrm{K}$ in the soil to meet plant requirements. According to Comissão de Química e Fertilidade do Solo (CQFS RS/SC, 2016), $\mathrm{K}$ levels in the soil must range from 61 to $90 \mathrm{mg} \mathrm{kg}^{-1}$ for wine grape production. Furthermore, although $\mathrm{K}$ is the macronutrient mostly absorbed (greatest amounts) by grapevines, which reflects on $\mathrm{K}$ amount exported via cluster, its functions comprise osmotic potential maintenance, enzyme activation in carbohydrate metabolism, photosynthesis and protein synthesis (KODUR, 2011).

Exchangeable K contents in the soil, which included $\mathrm{K}$ in solution and $\mathrm{K}$ adsorbed by functional groups of soil reactive particles, most likely sufficed to meet plant requirements. Thus, plants' response to fertilization may not have happened for reasons linked to K availability. One of the reasons lies on the fact that non-exchangeable $\mathrm{K}$ found in the interlayer of clay minerals may have quickly replaced the K uptaken by plants. Vermiculite, which is a 2: 1 clay silicate capable of fixing and releasing $\mathrm{K}$ from interlayers, was the soil used in the current study (PARK et al., 2019). Furthermore, K cycling deriving from waste deposition on the surface of the soil or plant root may have happened, whereas $\mathrm{K}$ available in the pruned grape material, roots or cover crops may have been released back into the soil (BRUNETTO et al., 2012; BRUNETTO et al., 2016; LEHMANN et al., 2016). All these factors may have contributed to decrease grapevine response to $\mathrm{K}$ fertilization.

Although K has failed to increase grape yield or to affect its parameters, it is recommended replenishing this nutrient in the soil on a yearly basis (CQFS-RS/SC, 2016). This practice aims the replenishment of soil that has had its $\mathrm{K}$ amount exported via cluster to enable maintaining proper $\mathrm{K}$ contents in the soil. These results are similar to those observed by Boonterm et al. (2010).

Grape yield was greater in all treatments applied in the 2010/11 growing season than in all other seasons, mainly because the 2010/11 growing season faced better climate conditions. Hail was observed during the 2011/12 growing season, which decreased cluster yield per plant, as well as the number of clusters and cluster mass. The number of clusters and cluster mass recorded the highest values in the 2010/11 growing season and the lowest values in 2011/12. The mass of 100 berries was similar in the 2010/11 and 2011/12 growing seasons and higher than in the $2012 / 13$ growing season, most likely because of different cluster growth conditions in the period, mainly if one takes into consideration the rainfall distribution. Rainfall volume in the cluster growth period (January) in the 2012/13 growing season was smaller than that of previous growing seasons. Increased cluster mass resulted from water and solute absorption, mainly sugars. Potassium (K) addition to the soil has failed to increase total $\mathrm{K}$ contents in berries in all growing seasons, likely because $\mathrm{K}$ contents in the soil were sufficient to meet plant requirements. Part of the applied $\mathrm{K}$ was available in the soil; it was absorbed by plants and mainly stored in leaves, as evidenced by increased $\mathrm{K}$ contents in leaf blades in the 2011/12 growing season, as well as in leaf blades and petioles in the 2012/13growing season.

Values recorded for TSS, $\mathrm{pH}$ and total titratable acidity in must were not affected by $\mathrm{K}$ fertilizer application in all three analyzed growing seasons (Table 4). It happened because total $\mathrm{K}$ contents in berries did not increase after fertilizer application (Table 3). Thus, plants absorbed and accumulated $\mathrm{K}$ in their leaves, even at medium or high $\mathrm{K}$ contents in the soil, in all treatments (medium $=$ from 61 to $90 \mathrm{mg} \mathrm{kg}^{-1}$, high $=$ from 91 to 180 $\mathrm{mg} \mathrm{kg}^{-1}$, in soils presenting $\mathrm{CEC}_{\mathrm{pH} 7.0}>15 \mathrm{cmol}_{\mathrm{c}} \mathrm{kg}^{-1}$; CQFS$\mathrm{RS} / \mathrm{SC}, 2016$ ); however, $\mathrm{K}$ content in berries and must did not increase. Dooa et al (2019) and El-Badwy (2019) observed increased TSS content in different grapevine cultivars subjected to increased $\mathrm{K}$ application levels. Other factors, such as initial $\mathrm{K}$ levels in leaves and fruits, as well as climate conditions during ripening, may also influence grape composition. 
Table 4. Values recorded for total soluble solids (TSS), $\mathrm{pH}$ and total titratable acidity in Cabernet Sauvignon grapevines subjected to different $\mathrm{K}$ fertilizer application rates for three growing seasons.

\begin{tabular}{|c|c|c|c|c|}
\hline Dose & TSS & $\mathrm{pH}$ & $\begin{array}{c}\text { Total titratable } \\
\text { acidity }\end{array}$ & TSS/acidity Ratio \\
\hline$\left(\mathrm{kg} \mathrm{ha}^{-1}\right.$ of year-1 $\left.\mathrm{K}_{2} \mathrm{O}\right)$ & ${ }^{\circ}$ Brix & & $\mathrm{g} \mathrm{L}^{-1}$ & \\
\hline 0 & $21.82^{\mathrm{ns}}$ & $2.62^{\mathrm{ns}}$ & $151^{\mathrm{ns}}$ & $145.4^{\text {ns }}$ \\
\hline 50 & 22.66 & 2.63 & 149 & 152.4 \\
\hline 100 & 21.94 & 2.72 & 149 & 147.5 \\
\hline 150 & 22.06 & 2.66 & 148 & 151.0 \\
\hline 200 & 21.92 & 2.73 & 149 & 147.0 \\
\hline $\mathrm{CV} \%$ & 3.97 & 6.77 & 6.27 & \\
\hline 0 & $23.52^{\mathrm{ns}}$ & $\begin{array}{l}11 / 2012 \\
2.97^{\mathrm{ns}}\end{array}$ & $107^{\mathrm{ns}}$ & $222.0^{\text {ns }}$ \\
\hline 50 & 23.64 & 3.02 & 102 & 233.6 \\
\hline 100 & 23.48 & 3.01 & 105 & 225.3 \\
\hline 150 & 23.35 & 3.00 & 104 & 226.8 \\
\hline 200 & 23.7 & 3.00 & 102 & 232.2 \\
\hline $\mathrm{CV} \%$ & 1.65 & 1.47 & 7.03 & \\
\hline 0 & $21.14^{\mathrm{ns}}$ & $\begin{array}{r}2 / 2013- \\
3.04^{\mathrm{ns}}\end{array}$ & $73^{\text {ns }}$ & -------- \\
\hline 50 & 21.20 & 3.06 & 69 & 310.8 \\
\hline 100 & 21.12 & 3.06 & 72 & 293.5 \\
\hline 150 & 21.12 & 3.06 & 69 & 310.2 \\
\hline 200 & 21.08 & 3.08 & 69 & 306.0 \\
\hline $\mathrm{CV} \%$ & 1.34 & 2.36 & 7.62 & \\
\hline
\end{tabular}

$\mathrm{ns}=$ not significant at $5 \%$ probability level

\section{Principal Component Analysis}

Principal component 1 (factor 1) of the Principal Component Analysis (PCA) applied to the 2010/11 growing season accounted for $50.21 \%$ of data variance. It allowed separating the treatments without $\mathrm{K}$ fertilizer application and with $50 \mathrm{~kg} \mathrm{ha}^{-1}$ year ${ }^{-1}$ of $\mathrm{K}_{2} \mathrm{O}$ from the other treatments $\left(100,150\right.$ and $200 \mathrm{~kg} \mathrm{ha}^{-1} \mathrm{year}^{-1}$ of $\left.\mathrm{K} 2 \mathrm{O}\right)$ (Figure 1a). Similar results were observed for 100 and $150 \mathrm{~kg} \mathrm{ha}^{-1}$ of $\mathrm{K}_{2} \mathrm{O}$ rates (Figure 1a). Must $\mathrm{pH}$, acidity, soil $\mathrm{K}$, available $\mathrm{K}$ and non-exchangeable $\mathrm{K}$ were the variables presenting the strongest impact on principal factor 1. Furthermore, available and non-exchangeable K contents were highly correlated to each other. Principal factor 2 accounted for $30.79 \%$ of total variance; must TSS and berry $\mathrm{K}$ were the variables that mostly contributed to this result.

Factor 1 in the PCA accounted for $48.75 \%$ of data variance in the 2011/12 growing season (Figure 1b). Petiole K, must acidity and soil $\mathrm{K}$ were the most important variables in this analysis. Factor 2 accounted for $30.94 \%$ of data variance; berry $\mathrm{K}$ was the most important variable. Factor 1 of PCA has separated treatments with 0,50 and $100 \mathrm{~kg} \mathrm{ha}^{-1} \mathrm{year}^{-1}$ of $\mathrm{K}_{2} \mathrm{O}$ and accounted for $65.11 \%$ of data variance in the 2012/13 growing season. Petiole K, must $\mathrm{pH}$ and soil $\mathrm{K}$ were the variables that mostly contributed to this separation. All these variables were correlated to each other. Factor 2, which accounted for only $17.70 \%$ of total variance, has separated treatments with application of 150 and $200 \mathrm{~kg} \mathrm{ha}^{-1}$ year- $^{-1}$ of K2O (Figure 1c). Must yield, TSS and total titratable acidity were the variables that mostly contributed to this factor.

Overall, only the annual application of $150 \mathrm{~kg}$ ha $^{-1}$ year-1 of $\mathrm{K}_{2} \mathrm{O}$ provided enough $\mathrm{K}$ to maintain total $\mathrm{K}$ content in the soil. Moreover, the application of up to 100 $\mathrm{kg} \mathrm{ha}^{-1} \mathrm{year}^{-1}$ of $\mathrm{K} 2 \mathrm{O}$ did not maintain $\mathrm{K}$ content availability in plants (SIMONSSON et al., 2009). This finding suggests that $\mathrm{K}$ contents in the soil can decrease over the years. Thus, it may be necessary increasing $\mathrm{K}$ doses applied to it, although the current study did not find plants' response to K application. 

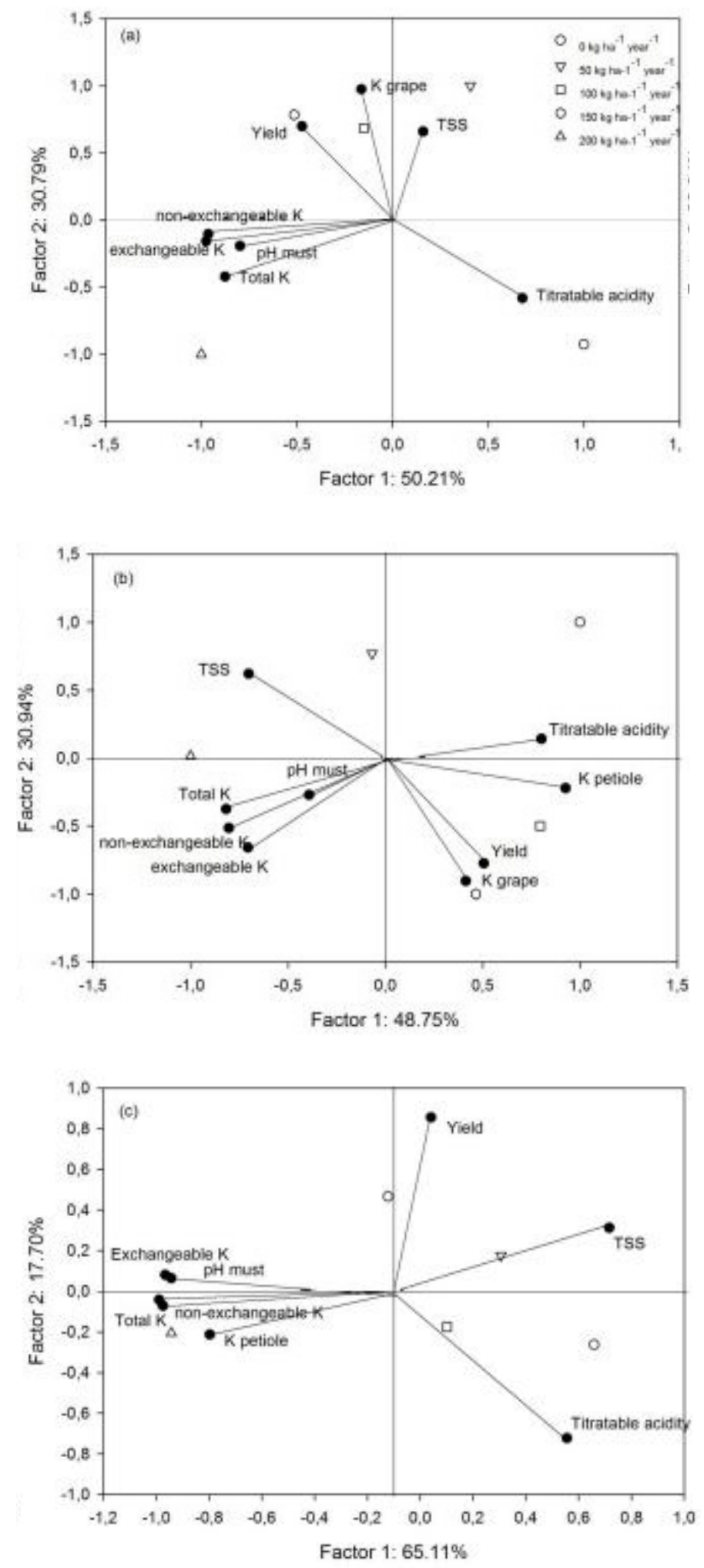

Figure 1. Principal Component Analysis (PCA) based on $\mathrm{K}$ content in leaf petiole, grape yield, $\mathrm{pH}$, titratable acidity and total soluble solids in grapes, $\mathrm{k}$ in berries, available $\mathrm{K}$, non-exchangeable and total $\mathrm{K}$ in the soil recorded for Cabernet Sauvignon grapevines subjected to different potassium fertilizer contents in the 2011 (a) 2012 (b) and 2013 (c) crops. 


\section{Conclusions}

Annual soil $\mathrm{K}$ fractionation into available, nonexchangeable and total soil $\mathrm{K}$ extracted with Mehlich-1, boiling $1 \mathrm{~N} \mathrm{HNO}_{3}$ and $\mathrm{HF}$, respectively, have suggested that $100 \mathrm{~kg} \mathrm{ha}^{-1}$ year ${ }^{-1}$ of $\mathrm{K}_{2} \mathrm{O}$ was the $\mathrm{K}$ dose capable of maintaining the availability of this nutrient to plants at more adequate contents throughout the growing seasons.

\section{References}

ARROBAS, M.; FERREIRA, I.Q.; FREITAS, S.; VERDIAL, J.; RODRIGUES, A. Guidelines for fertilizer use in vineyards based on nutrient content of grapevine parts. Scientia Horticulturae, Wageningen, v.172, p.191198, 2014.

BACHTELER, K.; RIEDEL, M.; MERKT, N.; ULLRICH, B.; ERHARDT, M.; WUNSCHE. J. Effect of soil fertilization on thein cidence of Berry shrivel and the quality of resulting wine. Vitis, Siebeldingen, v.52, p.17, 2013.

BENITO, A.; ROMERO, I.; DOMINGUEZ, N.; GARCIA-ESCUDERO, E.; MARTIN, I. Leaf blade and petiole analysis for nutrient diagnosis in Vitis vinifera L. cv. Garnacha tinta. Australian Journal of Grape and Wine Research, Oxford, v.19, n.2, p.285 -297, 2013.

BERTOLDI, D.; LARCHER, R.; BERTAMINI, M.; OTTO, S.; CONCHERI, G.; NICOLINI, G. Accumulation and distribution pattern of macro and microelements and trace elements in Vitis vinifera L cv. Chardonnay berries. Journal of Agricultural and Food Chemistry, Washington, v.59, p.7224-7236, 2011.

BOONTERM, V., SILAPAPUN, A.; BOONKERD, N. Effects of nitrogen, potassium fertilizer, and clusters per vine on yield and anthocyanin content in Cabernet Sauvignon grape. Suranaree Journal of Science and Technology, Thailand, v.17, p.155-163, 2010.

BRUNETTO G, CERETTA, C. A.; KAMINSKI, J. Concentrazione di potássio nelle bache e valori di $\mathrm{pH}$ e zuccheri nel mosto della cv Cabernet Sauvignon innestata su diversi portinnesti nel Sul del Brasile. Acta Italus Hortus, Firenze, v.3, p.636-639, 2012.
BRUNETTO G, ROZANE, D.E.; MELO, G.W.B.; ZALAMENA, J.; GIROTTO, E.; LOURENZI, C.; KAMINSKI. J. Manejo da fertilidade de solos em pomares de frutíferas de clima temperado. Manejo e conservação do solo e da água em pequenas propriedades rurais no sul do Brasil: práticas alternativas de manejo visando a conservação do solo e da água. Porto Alegre: UFRGS, 2016. cap. 9, p.141158. Disponível em: http://www.agrisus.org.br/arquivos/ livro_RGS.pdf(5)

CHAVES, E.; PEDRON, F. de A.; MELO, V. F. de; DALMOLIN. R.S.D. Reserva mineral de K por diferentes métodos em argissolos subtropicais. Revista Brasileira de Ciência do Solo, Viçosa, MG, v.39, n.4, p.1088-1099, 2015.

CIOTTA, M.N.; CERETTA, C.A.; SILVA, L.O.S. da; FERREIRA, P.A.A.; SAUTTER, C.K.; COUTO, R.D.R.; BRUNETTO. G. Grape yield, and must compounds of "Cabernet Sauvignon" grapevine in sandy with potassium contents increasing. Ciência Rural, Santa Maria, v.46, p.1376-1383, 2016.

CQFS - Comissão de Química e Fertilidade do Solo - RS/ SC. Manual de adubação e calagem para os Estados do Rio Grande do Sul e de Santa Catarina. 10. ed. Porto Alegre: SBCS - Núcleo Regional Sul/UFRGS, 2016. 400p.

DAL BO, M.A.; BETTONI, J.C.; GARDIN, J.P.P.; BASSO, C. Productivity and qualitu of grapes of cv. Isabel (Vitis labrusca L.) under potassium fertilization. Revista Brasileira de Fruticultura, Jaboticabal, v.37, n.3, p.789796, 2015.

DELGADO, R.; MARTIN, P.; DEL ÁLAMO, M.; GONZALEZ, M. R. Changes in the phenolic composition of grape beries during ripening in relation to vineyard nitrogen and potassium fertilization rates. Journal of the Science of Food and Agriculture, London, v.84, p.623630, 2004.

DOMAGALA-SWIATKIEWICZ, I.; GASTOL, M.; KISZKA, A. Effect of nitrogen and potassium fertilization on the magnesium content in vineyard soil, and in the leaves and berries of Bianca and Sibera grapevine cultivars. Journal of Elementology, Olsztyn, v.24, p.755$769,2019$. 
EL-BADAWY, H.E.M. Implication of using potassium and magnesium fertilization to improve growth, yield and quality of crimson seedless grapes (Vitis vinifera L.). Journal of Plant Production, Mansoura, v.10, n.2, p.133-141, 2019.

HELMKE, P.A.; SPARKS, D.L. Lithium, sodium, potassium, rubidium, and cesium. In: SPARKS, D.L. (ed.). Methods of soil analysis. Part 3. Chemical methods. Madison: Soil Science Society of America, 1996. p.551574.

HOU, W.; XUE, X.; LI, X.; KHAN, M. R.; YAN, J.; REN, T.; LU, J. Interactive effects of nitrogen and potassium on: Grain yield, nitrogen uptake and nitrogen use efficiency of rice in low potassium fertility soil in China. Field Crops Research, Amsterdam, v.236, p.14-23, 2019.

KAMIRI, R. Potassium-induced freezing tolerance is associated with endogenous abscisic acid, polyamines and soluble sugars changes in grapevine. Scientia Horticulturae, Wageningen, v.215, p.184-194, 2017.

KODUR S. Effects of juice $\mathrm{pH}$ and potassium on juice and wine quality, and regulation of potassium in grapevines through rootstocks (Vitis): a short review. Vitis. Siebeldingen, v.50, p.1-6, 2011.

LEHMANN, D.H.; CASSOL, P.C.; SACOMORI, W.; TEIXEIRA, A.K.F.; MAFRA, A.L.; ERNANI, P.R.E.; ZALAMENA, J. Cobertura do solo em vinhedos modifica os atributos do solo e o estado nutricional das videiras. Revista de Ciências Agroveterinárias, Lages, v.15, n.3, p.198-207, 2016.

KUMARAN P.B., K. VENKATESAN, A. SUBBIAH AND C.N. CHANDRASEKHAR Effect of pre-harvest foliar spray of potassium schoenite and chitosan oligosaccharide on yield and quality of grapes var. Muscat Hamburg. International Journal of Chemical Studies, Delhi, v.7, n.3, p.3998-4001, 2019.

LESTER, G.E.; JIFON, J.L.; MAKUS, D.J. Impact of potassium nutrition on food quality of fruit sand vegetables. Better Crops, New York, v.94, p.18-21, 2010 .

MEHLICH, A. Determination of $\mathbf{P}, \mathbf{C a}, \mathbf{M g}, \mathbf{K}, \mathbf{N a}$ and NH4 by North Carolina soil testing laboratories. Raleigh: University North Carolina, 1953.
MPELASOKA, B.S.; SHACHTMAN, D.P.; TREEBY, M.T.; THOMAS, M.R. A review of potassium nutrition in grapevines with special emphasis on berry accumulation. Australian Journal of Grape and Wine Research, Oxford, v.9, p.154-168, 2003.

OSAKABE, Y.; ARINAGA, N.; UMEZAWA, T.; KATSURA, S.; NAGAMACHI, K.; TANAKA, H.; YOSHIMURA. E. Osmotic stress responses and plant growth controlled by potassium transporters in Arabidopsis. The Plant Cell, Rockwille, v.25, p.609-624, 2013.

PARK, S.M.; ALESSI, D.S.; BAEK, K. Selective adsorption and irreversible fixation behavior of cesium onto 2: 1 layered clay mineral: A mini review. Journal of Hazardous Materials, Amsterdam, v.369, p.569-576, 2019.

PRADUBSUK, S.; DAVENPORT, J.R. Seasonal uptake and partitioning of macronutrients in mature 'Concord' grape. Journal of the American Society for Horticultural Science, Alexandria, v.135, p.474-483, 2010 .

PRATT, P.F. Potassium. In: BLACK, C.A. (ed.). Methods of soil analysis. Madison: Soil Science Society of America, 1965. p.1022-1030.

RAMOS, M.C.; ROMERO, M.P. Potassium uptake and redistribuition in Cabernet Sauvignon and Syrah grape tissues and its relationships with grape quality parameters. Journal of the Science of Food and Agriculture, New York, v.97, n.10, p.3268-3277, 2016.

ROGIERS, S.Y.; COETZEE, Z.A.; WALKER, R.R. Potassium in the Grape (Vitis vinifera L.) Berry: Transport and Function. Frontiers in Plant Science, Hyderabad, v.8, p.1629, 2017.

SHANGE, L.P.; CONRADIE, W. Effects of Soil parent material and climate on the performance of Vitis vinifera L. cvs. sauvignon blanc and cabernet sauvignon - part II. climate, leaf analysis, juice analysis and wine quality. South African Journal of Enology e Viticulture, Stellenbosch, v.33, p.174-183, 2012.

SILVA, A.C.; RODRIGUES. E.A.G. A viticultura nas microrregiões do Rio Grande do Sul e sua distribuição locacional. Orbis Latina, Foz do Iguaçu, v.8, p.5-20, 2018. 
SIMONSSON, M.; HILLIER, S,; ÖBORN, I. Changes in Clay mineral sand potassium fixation capacity as a result of release and fixation of potassium in long-term Field experiments. Geoderma, Amsterdam, v.151, p.109-120, 2009.

STELLACCI, A.M.; ARMENISE, E.; CALLIANDRO, A.; RUBINO. P. Relationships between soil characteristics and leaf nutrient concentrations in grapevine. Acta Horticulturae, The Hague, v.868, p.135-142, 2010.

TAGLIAVINI M.; SCANDELLARI. F. Methodologies and concepts in the study of nutrient uptake requirements and partitioning in fruit trees. Acta Horticulturae, The Hague, v.984, p.47-56, 2013.

TEIXEIRA, L.A.; TECCHIO, M.A.; MOURA, M.F.; TERRA, M.M.; PIRES, E.J.P.; HERNANDES, J.L. Alterações em atributos químicos de um solo submetido à adubação e cultivado com videira 'Niagara Rosada'. Revista Brasileira de Fruticultura, Jaboticabal, v.33, n.3, p.983-992, 2011.
WALKER, R.R.; BLACKMORE, D. H. Potassium concentration and $\mathrm{pH}$ inter-relationships in grape juice and wine of Chardonnay and Shiraz from a range of rootstocks in different environments. Australian Journal of Grape and Wine Research, Oxford, v.18, p.183-193, 2012.

ZLÁMALOVÁ, T.; ELBL, J.; BAROŇ, M.; BĚLÍKOVÁ, H.; LAMPÍŘ, L.; HLUŠEK, J.; LOŠÁK, T. Using foliar applications of magnesium and potassium to improve yields and some qualitative parameters of vine grapes (Vitis vinifera L.). Plant, Soil and Environment, Prague, v.61, n. 10, p.451-457, 2015. 